\title{
Comparison of Interleaved Boost Converter Configurations for Solar Photovoltaic System Interface
}

\author{
R Ramaprabha*a, K Balaji, SB Raj and VD Logeshwaran \\ Department of Electrical and Electronics Engineering, SSN College of Engineering, Rajiv Gandhi Salai, Kalavakkam- \\ 603110, Chennai, Tamilnadu, India
}

Received 18 December 2012; accepted 13 March 2013

\begin{abstract}
Solar photovoltaic (SPV) panels that convert light energy into electrical energy through the photovoltaic effect have nonlinear internal resistance. Hence, with the variation in the intensity of light falling on the panel, the internal resistance varies. For effective utilization of the SPV panel, it is necessary to extract the maximum power from it. For maximum power extraction from SPV panels, DC-DC converter interface is used. The problem in using high frequency converter interface is the resultant high frequency ripple interaction with the SPV system. In this work, an interleaved boost converter (IBC) is considered to reduce the ripple. Our finding is that IBC fed by a SPV panel reduces this ripple to a greater extent. IBC also has a faster transient response as compared to conventional boost converters with reduced ripple contents. The main aim of this paper is to present a comparative analysis of the performance of IBC with inductors that are coupled in different ways. The results of the simulation were extrapolated with the help of MATLAB software and verified through experimentation.
\end{abstract}

Keywords: Solar photovoltaic system, Interleaved boost converter, Ripple reduction, Comparison, MATLAB

$$
\text { مقارنة لتكوينات متداخلة من محولات رفع متقطعة لأنظمة الطاقة الشمسية الكهروضوئية }
$$

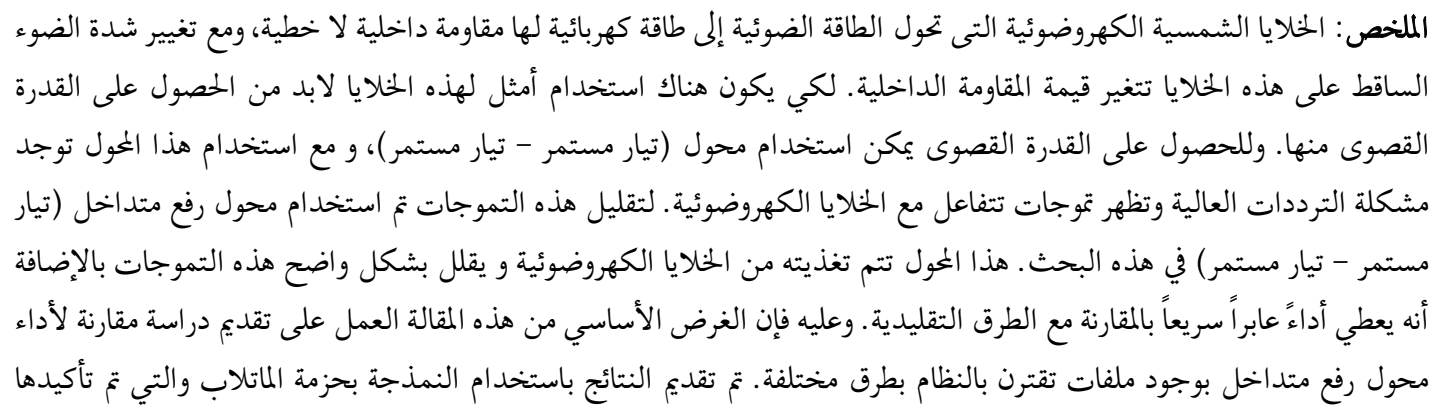




\section{Introduction}

In recent years, there has been a huge increase in the demand for power due to rapid industrial growth, along with an increase in residential loads. As it is necessary to meet these increasing power demands, and since non-renewable energy resources such as fossil fuels are quickly being depleted, alternative, renewable energy resources such as wind energy, solar energy, hydroelectric energy, and bio-mass energy have become major areas of research.

Solar energy is one of the most reliable sustainable energy sources and does not require waste management nor pollute the environment. In order to boost the voltage output from SPV panels, a boost converter is employed (Braga and Barbi 1999; Miyatake et al. 2011). The conventional boost converter, when interfaced with an SPV panel, has a high ripple in the voltage and current waveforms on both the input and output sides (Veerachary et al. 2001). When IBC is used, the ripple is reduced.

Multiple boost converters connected in parallel form the IBC circuit (Phani and Veerachary 2006; Tseng et al. 2007). Due to variations in environmental conditions, the insolation level varies; hence, the power output from the panel varies. For instance, in shaded conditions as SPV power decreases, just a few converters are sufficient to transfer the power whereas under high-light conditions when SPV power goes high, additional converters are employed to share the power. When the inductors of the IBC are mutually coupled, there is a greater reduction in the ripple content than in cases where they are left uncoupled (Veerachary et al. 2003). The current through the converter gets divided among the parallel branches; hence, there is reduction in the stress on the power electronic devices employed as well as a reduction in losses. The only disadvantage is the rise in cost. However, this rise is not significant since lower rating devices may be employed as the current is divided between the parallel branches.

In this paper, an analysis of an SPV-fed interleaved boost converter (IBC) was carried out. An IBC with two boost converters connected in parallel was considered for this work. The performance of the conventional boost converter, non-coupled IBC, directly coupled IBC, and inverse coupled IBC were compared by means of simulation as well as hardware implementation. Simulation of the system was carried out using MATLAB/Simulink (MathWorks, Inc., Nattick, Massachusetts, USA).

\section{System Description}

The components of the studied system include the
SPV panel, a boost converter (conventional or IBC), load ( $\mathrm{R}$ or $\mathrm{R}-\mathrm{L})$, maximum power point tracking (MPPT) using an incremental conductance (INC) algorithm and pulse generating circuit. For the purpose of analysis, the following assumptions have been made:

a) N-type metal oxide semiconductor field effect transistors (MOSFETs) and diodes of the converter are assumed to be ideal.

b) Both the branches in the case of IBCs are assumed to be identical, and they operate in continuous conduction mode (CCM).

c) Linear time invariant passive elements are used.

The schematic diagram of the system under consideration is shown in Fig. 1. Design, modelling, and simulation of each section in the schematic is discussed below.

\subsection{Mathematical Model of PV System}

A group of SPV cells together form the SPV power generation system. The following equations are used for the mathematical modeling of the SPV cell (Gow and Manning 1996; Walker 2001; Duffie and Beckman 2006; Villava et al. 2009). The output current from the SPV panel is given as

$$
I_{p v}=I_{p h}-I_{D}-I_{s h}
$$

Photon generated current of the SPV panel, $\mathrm{I}_{\mathrm{ph}}$, is given as

$$
I_{p h}=\left\{K_{i}\left(T-T_{n}\right)+I_{p v n}\right\} \frac{G}{G_{n}}
$$

The current through the diode is calculated as

$$
\left.I_{D}=I_{r}\left\{\exp \mid\left(V_{p v}+I_{p v} R_{s e}\right) V_{t a}-1\right]\right\}
$$

and

$$
I_{r}=\frac{K_{i}\left(T-T_{n}\right)+I_{s c n}}{\exp \left[\left(K_{v}\left(T-T_{n}\right)+V_{o c n}\right) V_{t a}\right]-1}
$$

Equations (1)-(4) are used for modeling the SPV system. A MATLAB model of the SPV panel to plot the characteristics is shown in Fig. 2. For insolation, $\mathrm{G}=1000 \mathrm{~W} / \mathrm{m}^{2}$ and temperature, $\mathrm{T}=250^{\circ} \mathrm{C}$, the characteristics of the SPV panel consisting of 36 cells in series is shown in Fig. 3. 


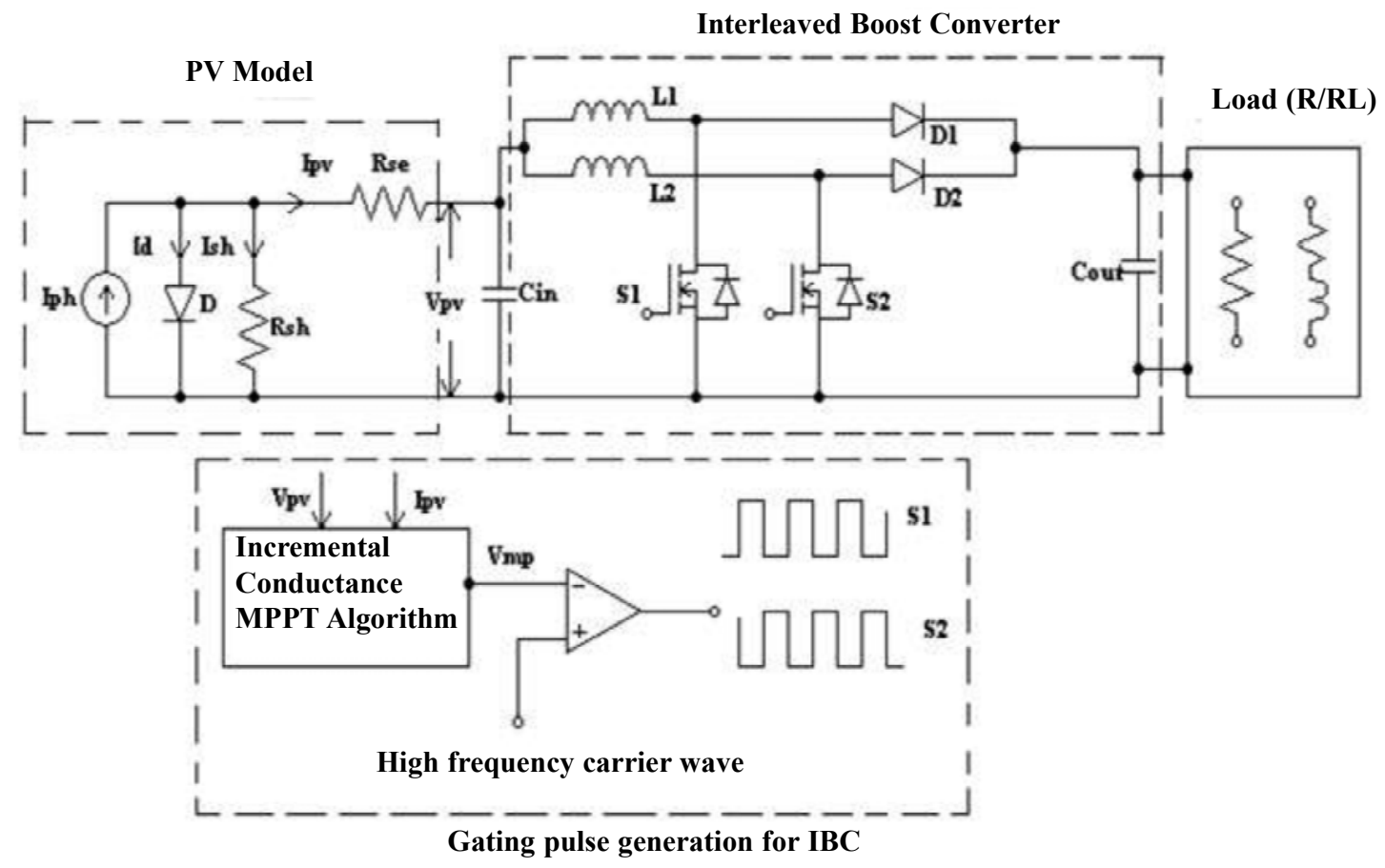

Figure 1. Schematic of the system

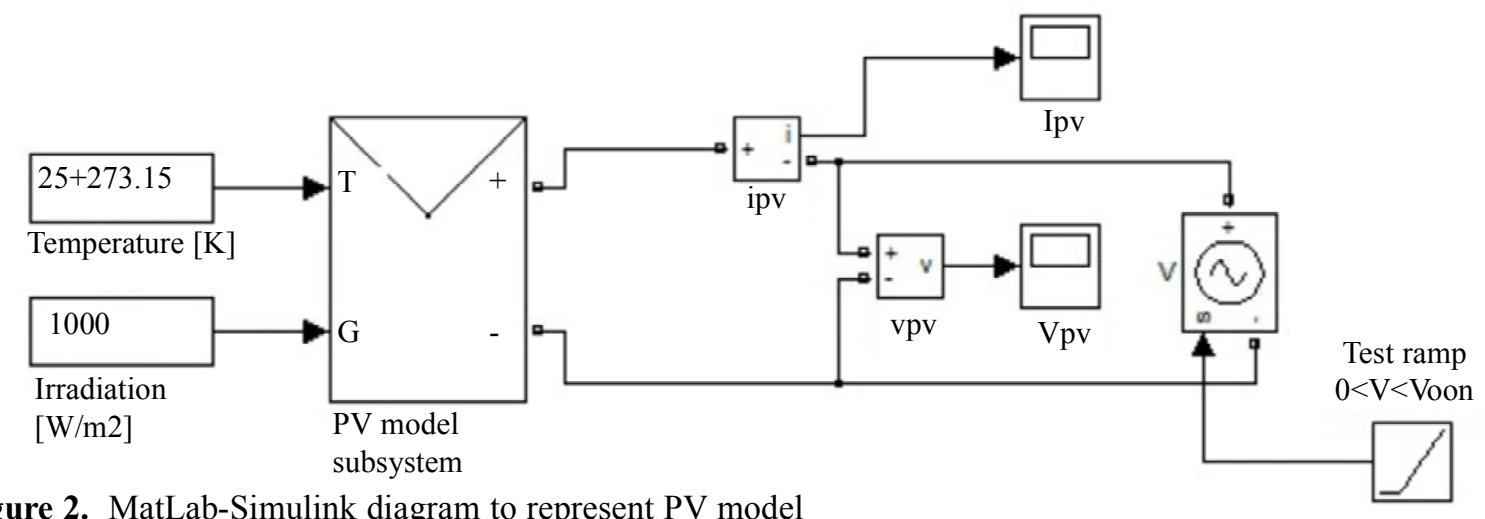

Figure 2. MatLab-Simulink diagram to represent PV model
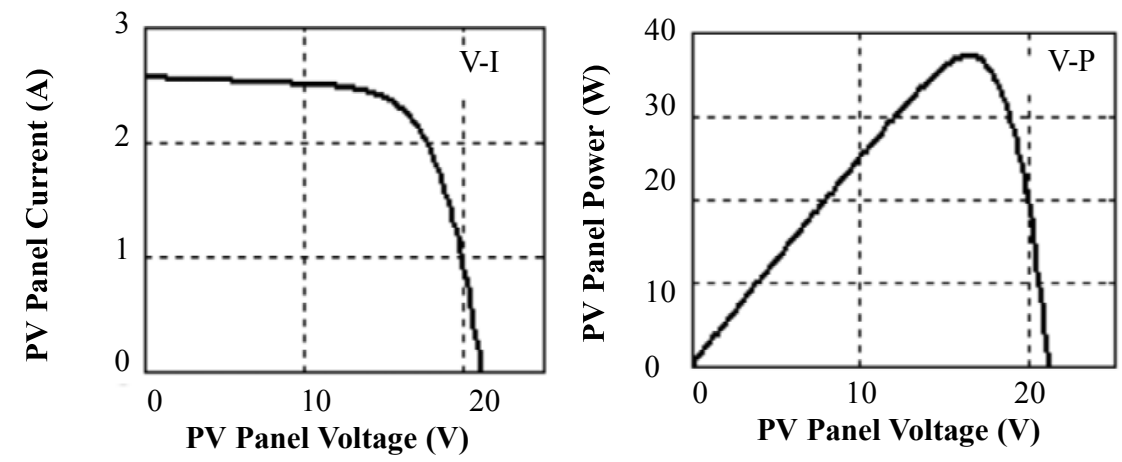

Figure 3. Simulated PV characteristics

\subsection{Design and Simulation of Interleaved Boost Converter}

As the efficiency of SPV system is only about 13$16 \%$ for the silicon mono/poly crystalline types which are commonly used, the power produced by it should be efficiently utilized. To achieve this, converters are

used as MPPTs (Braga and Barbi 1999; Rashid 2001; Veerachary et al. 2001; Salas et al. 2006). Among the converters proposed in literature, the boost converter is found to be most efficient (Wang 2009; Ibrahim and Saban 2010). However, the normal boost converters do not satisfy all requirements, such as low value of 
ripple in the inductor current in the input side and highly efficient operation even at lower insolation levels. For this purpose, two such boost converters are put in parallel and operated as IBCs. Although IBC overcomes the drawbacks of conventional boost converters, its static and dynamic performances are poor. Hence, a new model consisting of coupled inductors in parallel are used (Thounthong 2008; Ho et al. 2011). These coupled inductors reduce the ripple content in the inductor current on the input side by interleaving principles (Wang 2009).

Boost converter design equations are given from Eqns. 5 - 8. The values of $\mathrm{L}$ and $\mathrm{C}$ are (Lee at al. 2000; Shin et al. 2005) decided based on (7) and (8).

$$
\mathrm{V}_{\mathrm{S}} \mathrm{DT}=\frac{\mathrm{V}_{\mathrm{O}}-\mathrm{V}_{\mathrm{S}}}{(1-\mathrm{D}) \mathrm{T}}
$$

From which the DC voltage transfer function turns out to be,

$$
\mathrm{M}_{\mathrm{V}}=\frac{\mathrm{V}_{\mathrm{O}}}{\mathrm{V}_{\mathrm{s}}}=\frac{1}{1-\mathrm{D}}
$$

As the name of the converter suggests, the output voltage is always greater than the input voltage. The boost converter operates in the CCM for $\mathrm{L}>\mathrm{L}_{\mathrm{b}}$ where,

$$
\mathrm{L}_{\mathrm{b}}=\frac{\left(1-\mathrm{D}^{2}\right) \mathrm{DR}}{2 \mathrm{f}}
$$

The current supplied to the output RC circuit is discontinuous. Thus, a larger filter capacitor is required to limit the output voltage ripple. The filter capacitor $\mathrm{C}_{\text {min }}$ must provide the output DC current to the load when the diode $\mathrm{D}$ is off. The minimum value of the filter capacitance results in the ripple voltage $V_{r}$ is given by

$$
\mathrm{C}_{\min }=\frac{\mathrm{DV}_{\mathrm{o}}}{\mathrm{V}_{\mathrm{r} f} \mathrm{Rf}}
$$

The interleaved boost converters with coupled inductors are modeled using the following Eqns. (9)(11). The equivalent value of inductance is given by the expression

$$
\mathrm{L}_{\mathrm{eq}}=\frac{\mathrm{DV} \mathrm{T}}{\Delta \mathrm{I}}
$$

Self-inductance and mutual inductance are calculated as

$$
\mathrm{L}_{\mathrm{m}}=\beta \mathrm{L} \text { and } \mathrm{L}_{\mathrm{s}}=(1-\beta) \mathrm{L}
$$

where $L=\frac{1+\beta \frac{D}{1-D}}{1+\beta-2 \beta^{2}} L_{\text {eq }}$

The value of capacitance is decided by the equation

$$
\mathrm{C}=\frac{\mathrm{DV}_{\mathrm{o}} \mathrm{T}}{\mathrm{R} \Delta \mathrm{V}_{\mathrm{O}}}
$$

The inductors are connected in three ways as shown in Fig. 4.

\subsection{Maximum Power Point Algorithm}

The location of the maximum power point (MPP) in the V-I plane is not known beforehand and always changes dynamically depending on irradiance and temperature. Therefore, the MPP needs to be located by a tracking algorithm. A number of MPP calculation methods have been reported in the literature (Hussein et al. 1995). For this work the basic incremental conductance (INC) MPP algorithm is considered. The flowchart for the INC algorithm is shown in Fig. 5. The tracking of MPP with INC is shown in Fig. 6.

\section{Simulation Results}

The system shown in Fig. 1 was simulated using MATLAB-Simulink. Boost converter IBC with noncoupled inductors, directly coupled IBC, and IBC with inversely coupled inductors were simulated. The parameters used for simulation were

\section{SPV Panel}

(SOLKAR Panel- Model No. 3712/0507)

$\mathrm{I}_{\mathrm{scn}}=2.55 \mathrm{~A} ; \mathrm{V}_{\mathrm{ocn}}=21.24 \mathrm{~V}$;

$\mathrm{I}_{\mathrm{mp}}=2.25 \mathrm{~A} ; \mathrm{V}_{\mathrm{mp}}=16.56 \mathrm{~V} ; \mathrm{P}_{\mathrm{mp}}=37.08 \mathrm{~W}$.

\section{Converter}

$\mathrm{C}_{\text {in }}=100 \mathrm{uF} ; \mathrm{C}_{\text {out }}=100 \mathrm{uF} ; \mathrm{L}=200 \mathrm{uH} ; \mathrm{L}_{\mathrm{m} 1}=9.7 \mathrm{mH}$; $\mathrm{L}_{\mathrm{m} 2}=9.7 \mathrm{mH} ; \mathrm{R}_{\text {load }}=100 \Omega ; \beta=0.65$.

The current in coupled coils of directly coupled IBC is shown in Fig. 7. Simulation results for $G=900$ $\mathrm{W} / \mathrm{m}^{2}$ and $\mathrm{T}=250^{\circ} \mathrm{C}$ are presented in Figs. 8-11. Even though the average current in both conventional boost converters and IBC are the same, to highlight the reduction in ripple, the waveforms of the IBC are projected in different scales. Comparative results for the $\mathrm{R}$ and R-L loads are presented (Tables 1 and 2) on the ripple voltage and ripple current on both the input and output sides for different insolation levels.

\section{Hardware Implementation}

The SPV panel used for experimentation is shown in Fig. 12. From Table 2, it can be seen that IBC with directly coupled inductors had low ripple content for all parameters. Hence, the IBC with directly coupled inductors was implemented in the hardware by mounting the following components on a Hy-Lam sheet as shown in the Fig. 13. 


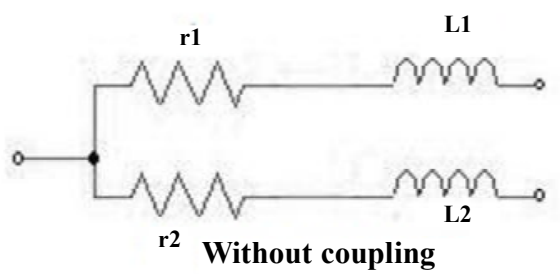

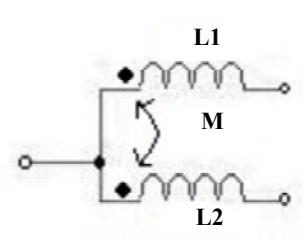

Direct coupling

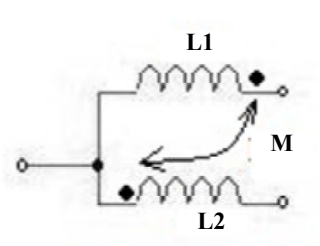

Inverse coupling

Figure 4. Different ways of coupling inductors in IBC

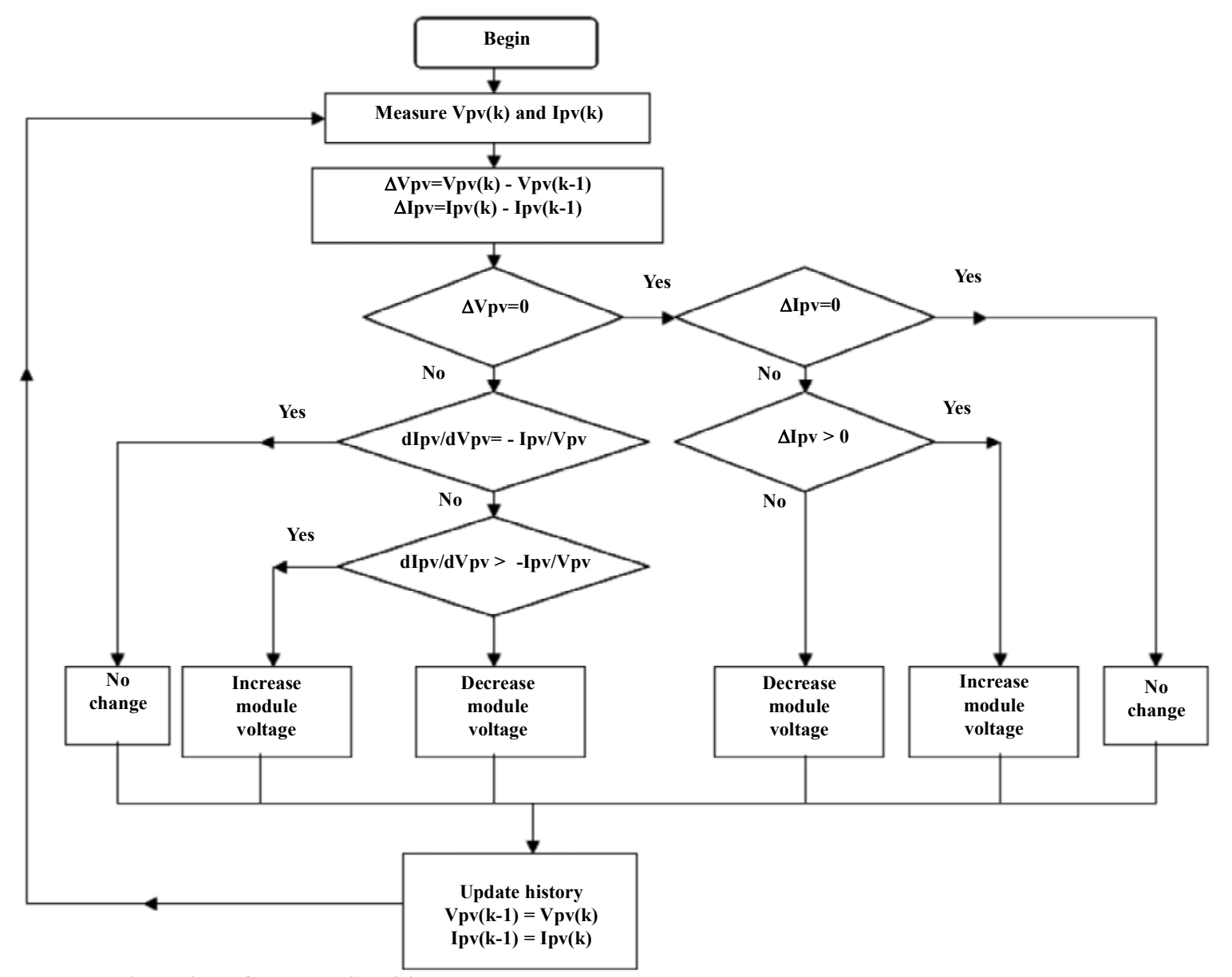

Figure 5. Flow chart for INC algorithm

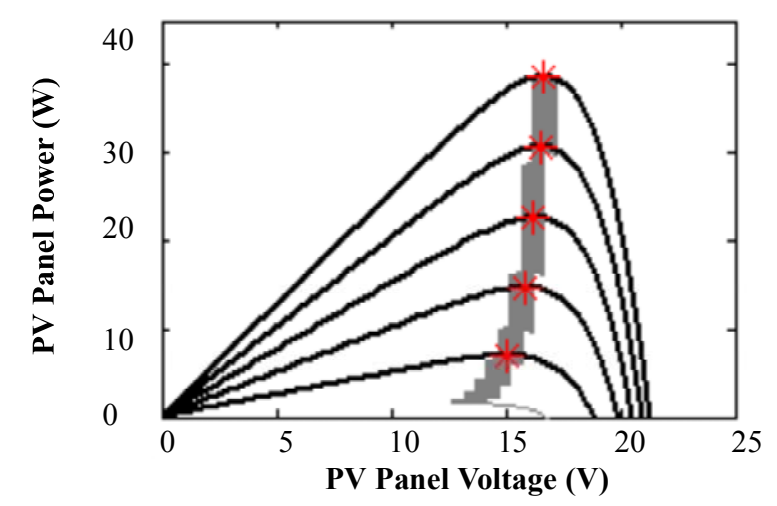

Figure 6. Simulation results for INC algorithm

IRFP 460 switches (MOSFET-TO-247 package type) with a rating of $500 \mathrm{~V}$ and $20 \mathrm{~A}$. 1N5408 diode with a $3 \mathrm{~A}$ current rating. An inductor designed by winding appropriate turns of insulated copper coil on an E-core. The components used included:
- Two inductors (mutually coupled) $120 \mathrm{mH}$ (each)

- Filter capacitor $220 \mu \mathrm{F}$

- Load resistance $100 \mathrm{ohm}$ 


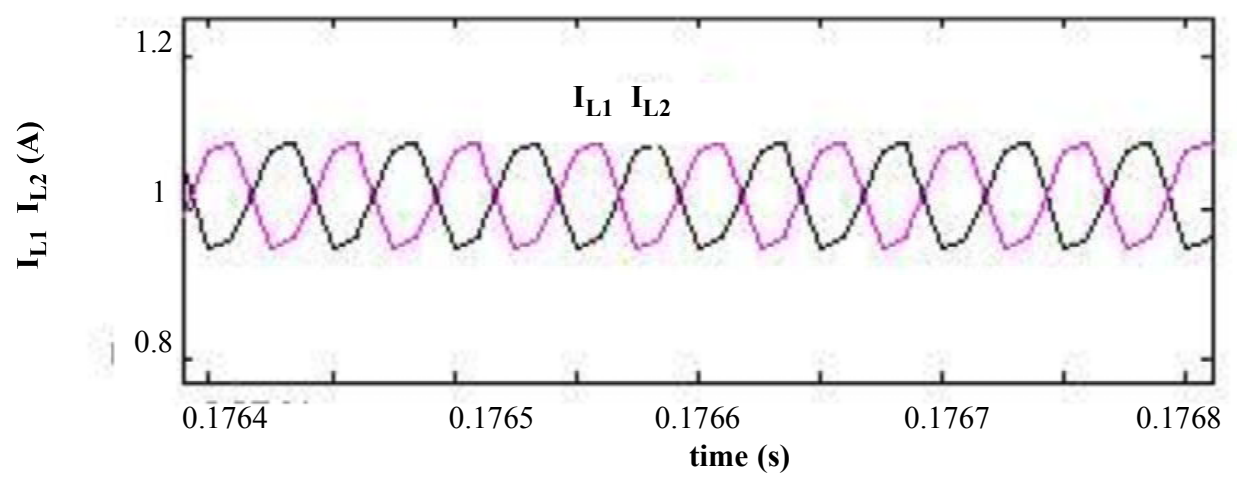

Figure 7. Current through coupled inductors of IBC
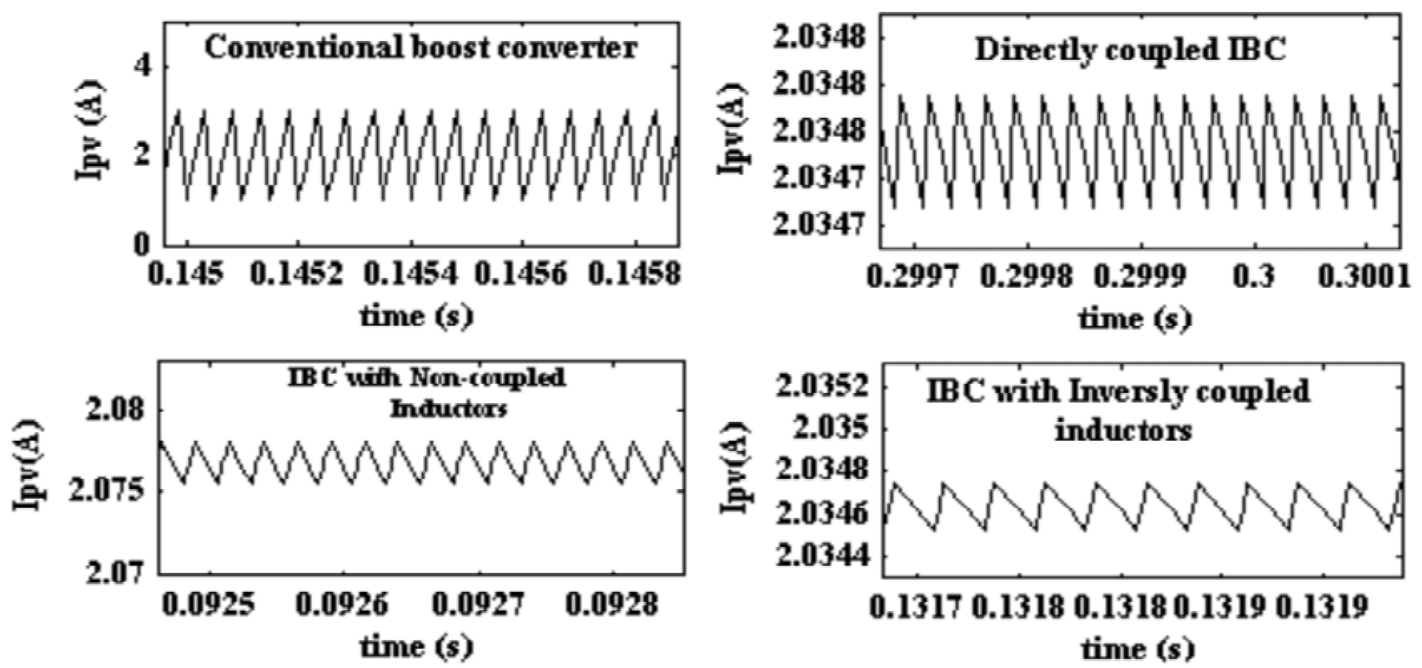

Figure 8. Comparison of input current ripple
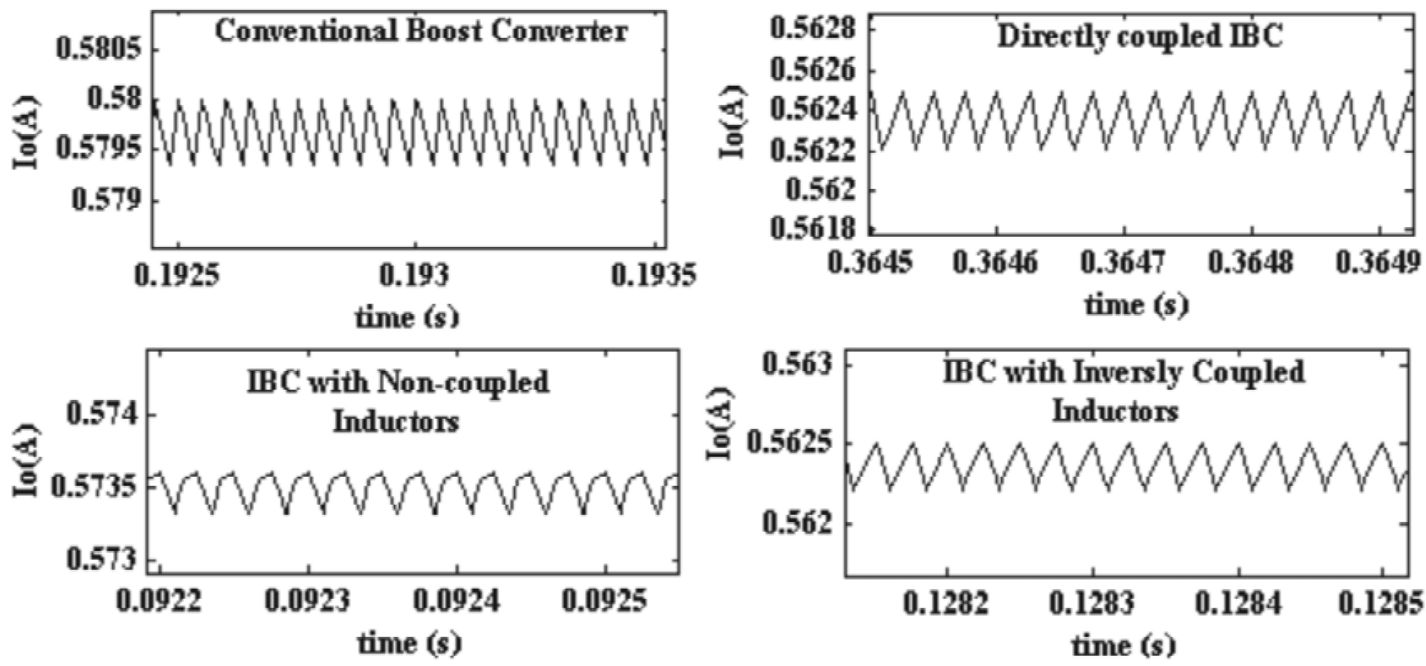

Figure 9. Comparison of output current ripple

A PIC18F4550 microcontroller is used for triggering the MOSFETs.

The two pulses that were $180^{\circ}$ out of phase are as shown in Fig. 14. The INC algorithm that traces the maximum power point for different conditions of inso-

lation is coded by means of position-independent code (PIC), and appropriate triggering pulses were generated so that such maximum power was obtained at the output side. The gating pulses were given to the devices by employing a MCT2E opto coupler to pro- 

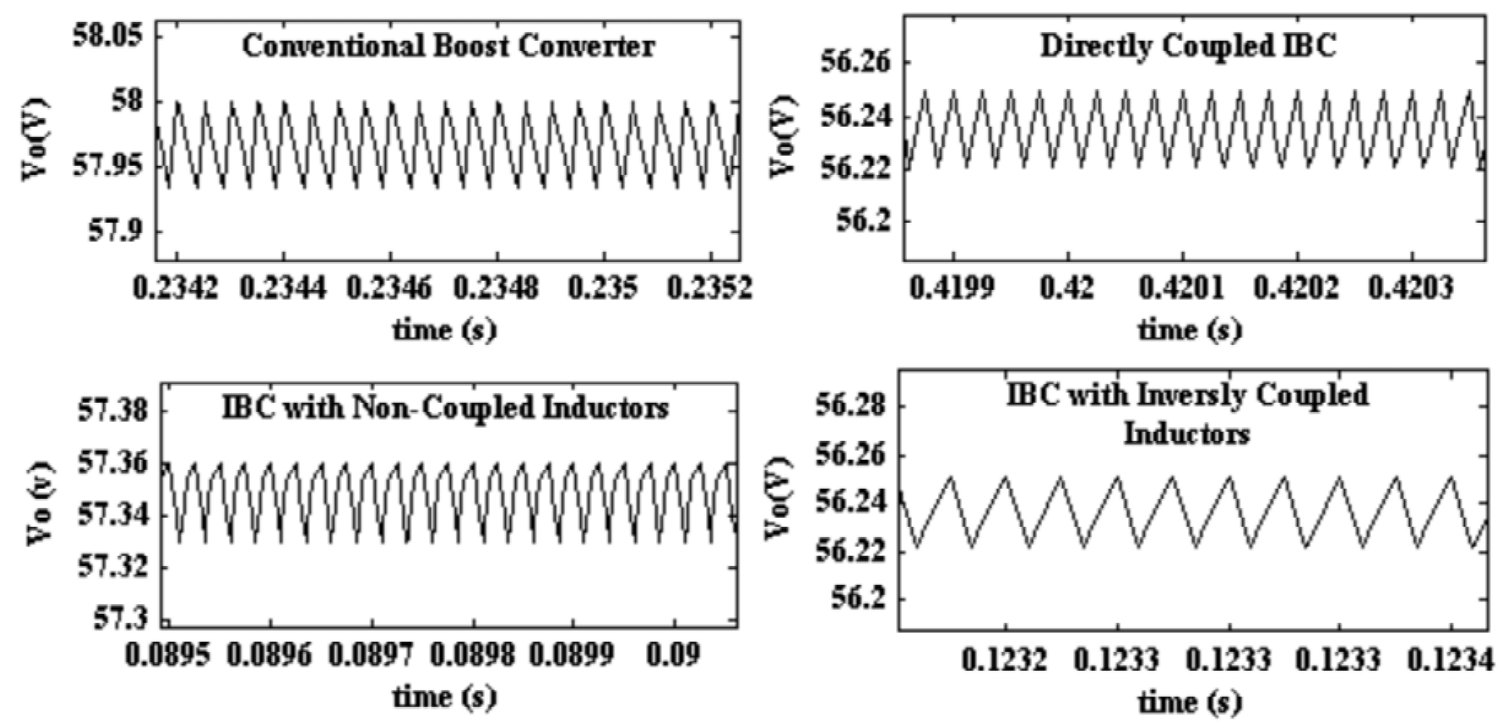

Figure 10. Voltage ripple comparison
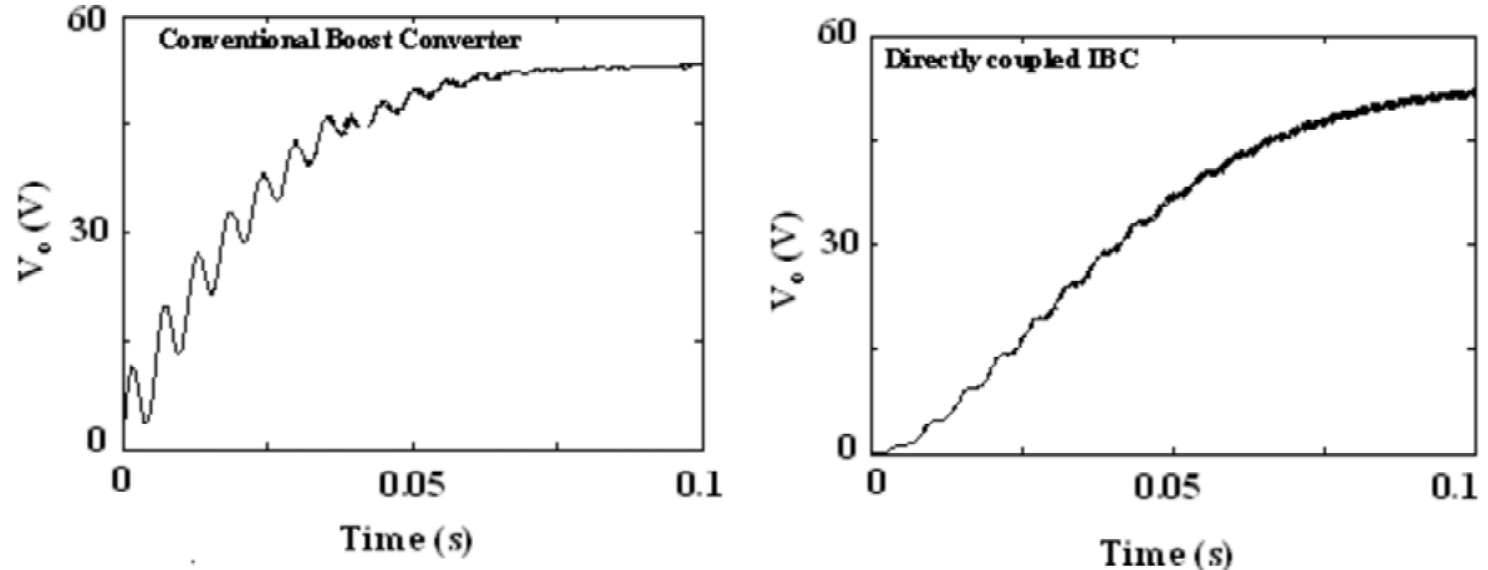

Figure 11. Voltage comparison - transient period

Table 1. Simulation results for $\mathrm{R}$ load

\begin{tabular}{|c|c|c|c|c|c|c|}
\hline $\begin{array}{l}\text { Type for Boost } \\
\text { Converter }\end{array}$ & $\begin{array}{c}\text { Input } \\
\text { Voltage(V) }\end{array}$ & $\begin{array}{c}\text { Input } \\
\text { Current(A) }\end{array}$ & $\begin{array}{c}\text { Output } \\
\text { Voltage(V) }\end{array}$ & $\begin{array}{c}\text { Output } \\
\text { Current(A) }\end{array}$ & $\begin{array}{c}\text { Input } \\
\text { Power(W) }\end{array}$ & $\begin{array}{c}\text { Output } \\
\text { Power(W) }\end{array}$ \\
\hline Conventional & 15.24 & 1.724 & 49.63 & 0.4963 & 26.27 & 24.63 \\
\hline $\begin{array}{l}\text { IBC with un- } \\
\text { coupled } \\
\text { inductors }\end{array}$ & 14.93 & 1.763 & 48.71 & 0.4871 & 26.32 & 23.73 \\
\hline $\begin{array}{l}\text { IBC with di- } \\
\text { rectly coupled } \\
\text { inductors }\end{array}$ & 15.24 & 1.749 & 48.3 & 0.483 & 26.67 & 23.33 \\
\hline $\begin{array}{l}\text { IBC with in- } \\
\text { versely coupled } \\
\text { inductors }\end{array}$ & 15.24 & 1.75 & 48.3 & 0.483 & 26.67 & 23.33 \\
\hline
\end{tabular}


Table 2. Comparison of ripple percentage for $\mathrm{R}$ load

\begin{tabular}{|c|c|c|c|c|}
\hline \multirow{2}{*}{$\begin{array}{l}\text { Type for Boost } \\
\text { Converter }\end{array}$} & \multicolumn{4}{|c|}{ Percentage of Ripple } \\
\hline & $\begin{array}{c}\text { Input Volt age } \\
(\%) \\
\end{array}$ & $\begin{array}{c}\text { Input Current } \\
(\%)\end{array}$ & $\begin{array}{c}\text { Output Voltage } \\
(\%)\end{array}$ & $\begin{array}{c}\text { Output Current } \\
(\%)\end{array}$ \\
\hline Conventional & 0.0656 & 0.232 & 0.161 & 0.161 \\
\hline $\begin{array}{l}\text { IBC with uncoup led } \\
\text { inductors }\end{array}$ & 0.089 & 0.141 & 0.041 & 0.05 \\
\hline $\begin{array}{l}\text { IBC with directly coupled } \\
\text { inductors }\end{array}$ & 0.024 & 0.008 & 0.012 & 0.008 \\
\hline $\begin{array}{l}\text { IBC with inversely } \\
\text { coupled inductors }\end{array}$ & 0.034 & 0.012 & 0.011 & 0.011 \\
\hline
\end{tabular}

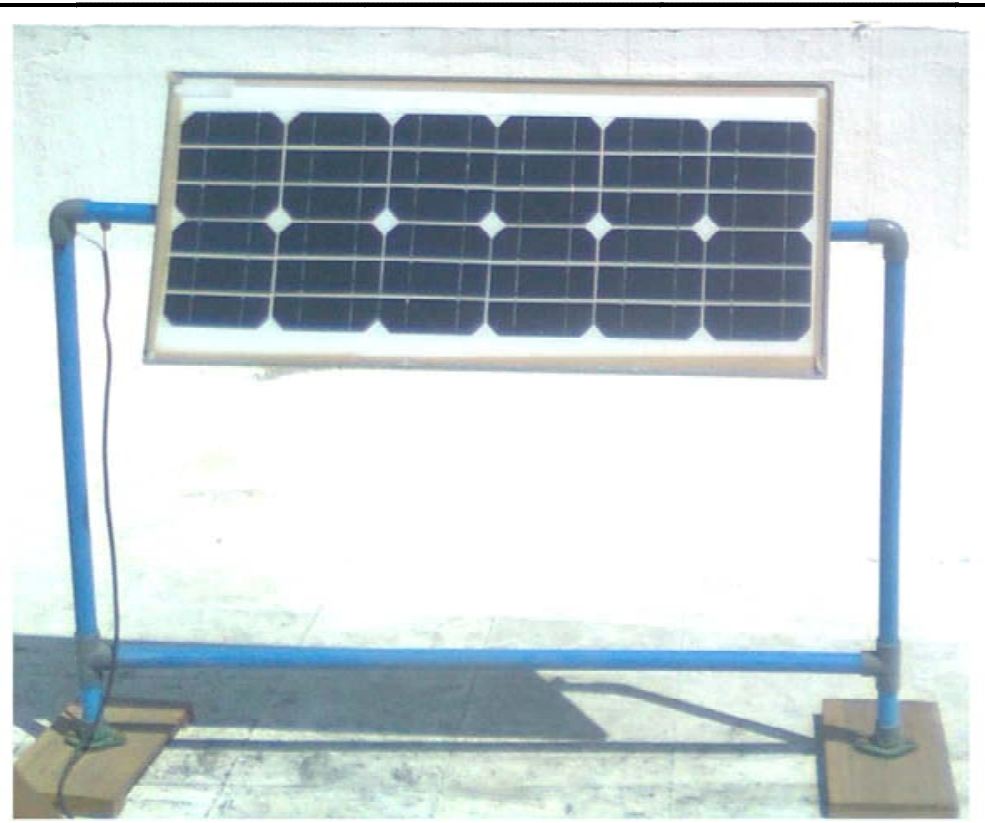

Figure 12. SOLKAR PV panel (Model \# 3712/0507) with tilting stand arrangement to change insolation levels

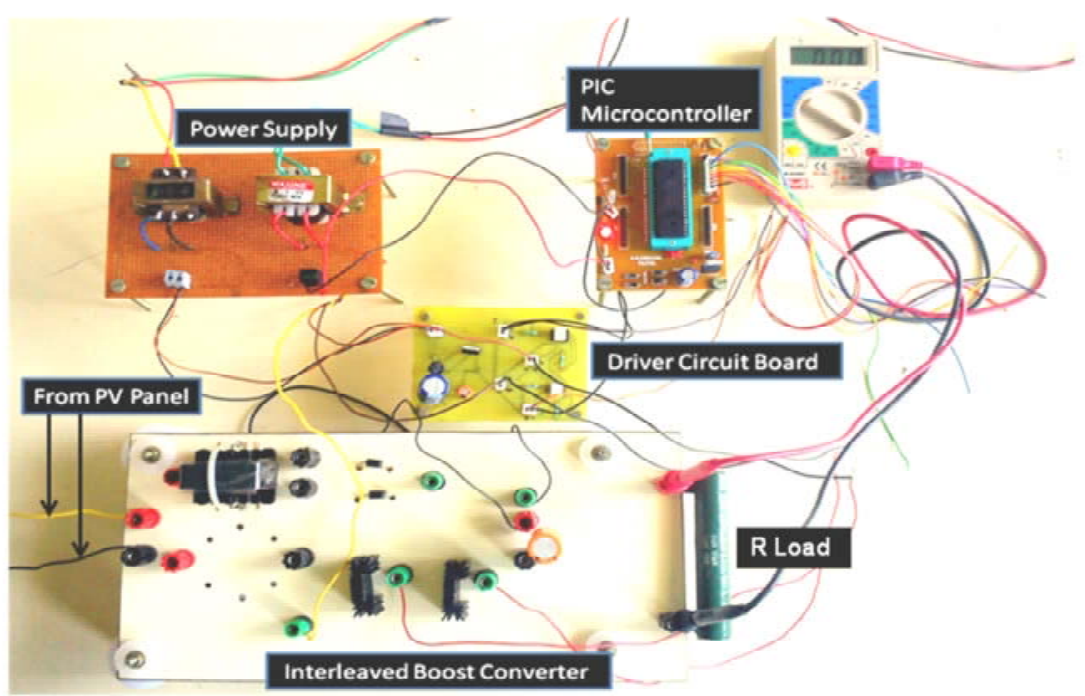

Figure 13. Hardware setup of the system

output of the converter was given to an R load. Figs. 15 and 16 show the input and output voltage and cur- rent waveforms of the system as observed on digital storage oscilloscope (DSO). 


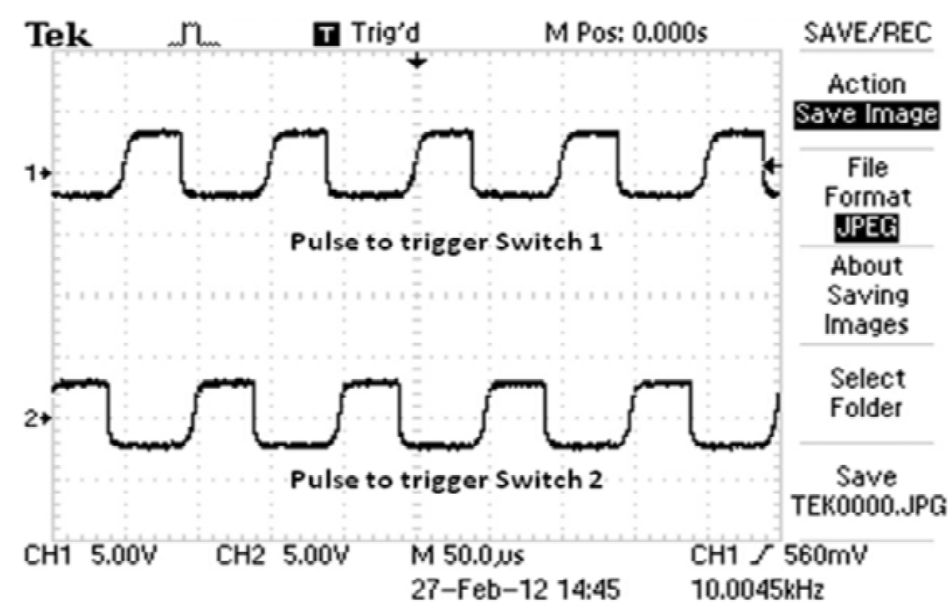

Figure 14. Pulses to trigger the MOSFETs

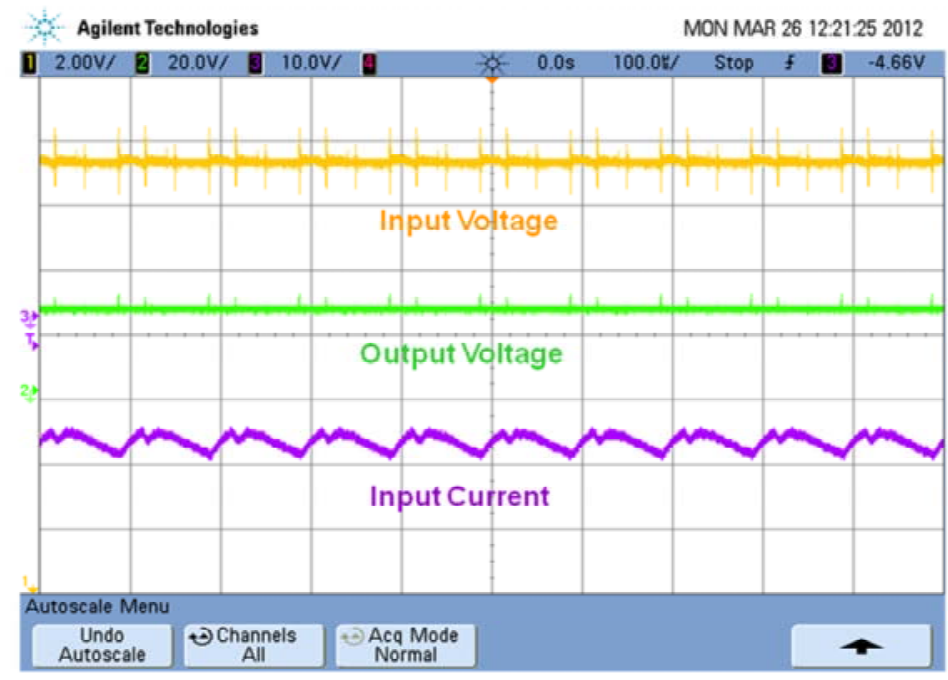

Figure 15. Voltage and input current waveforms observed on DSO

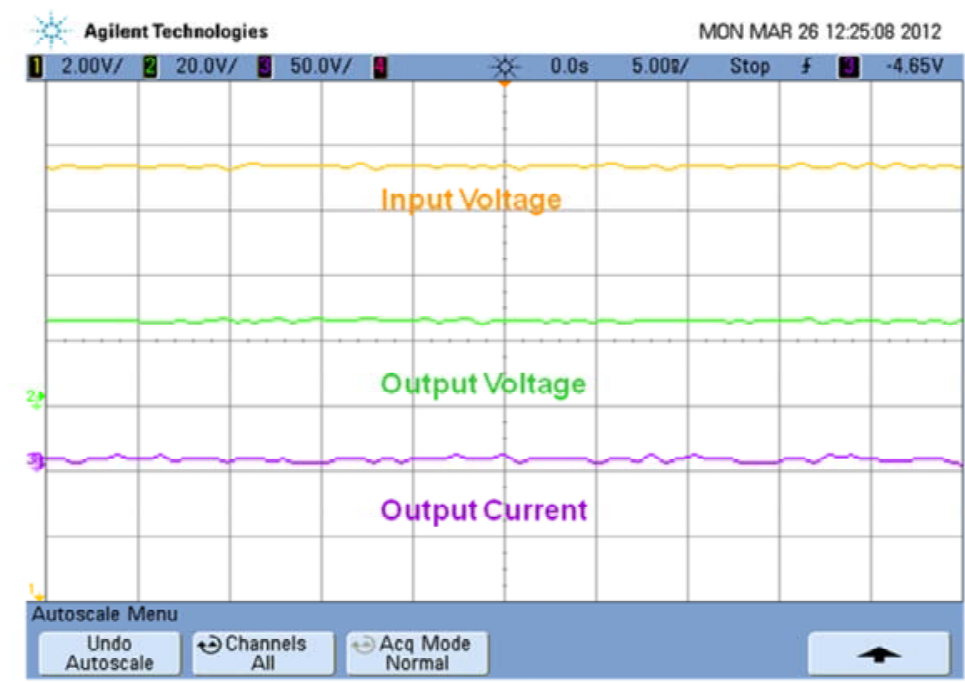

Figure 16. Voltage and output current waveforms observed in DSO

Figure 17 shows the parameters of input and output voltages of directly coupled IBCs, whereas Fig. 18 shows the parameters of the input and output current of directly coupled IBCs measured using a single 
Parameters of Input Voltage of IBC using Single Phase Clamp on Power Quality Analyzer

\begin{tabular}{|c|c|c|c|c|}
\hline एव Volts & 2012-03-26, 12:39 & एव Volts & -4 & $3-26,12: 39$ \\
\hline & $0.0 \mathrm{~Hz}$ & & & $0.0 \mathrm{~Hz}$ \\
\hline & & $\mathrm{Vac}$ & V avg & V pk \\
\hline 15.08 & r rms & 0.01 & 15.11 & 15.15 \\
\hline & $\mathrm{V} \mathrm{dc}$ & $\mathrm{V} / \mathrm{Hz}$ & $\%$ RPL & CF \\
\hline 15.08 & & OL & 0.05 & 1.00 \\
\hline
\end{tabular}

Parameters of Output Voltage of IBC using Single Phase Clamp on Power Quality Analyzer

\begin{tabular}{|c|c|c|c|c|}
\hline एव Volts & 2012-03-26, 12:40 & एव Volts & - & $03-26,12: 40$ \\
\hline & $0.0 \mathrm{~Hz}$ & & & $0.0 \mathrm{~Hz}$ \\
\hline & & $\mathrm{V}$ ac & V avg & V pk \\
\hline 46.94 & rms & 0.01 & 46.94 & 46.99 \\
\hline & $\mathrm{V} \mathrm{dc}$ & $\mathrm{V} / \mathrm{Hz}$ & $\%$ RPL & $\mathrm{CF}$ \\
\hline 46.94 & & OL & 0.02 & 1.00 \\
\hline
\end{tabular}

Figure 17. Parameters of input and output voltages of directly coupled IBC

\begin{tabular}{|c|c|c|c|c|}
\hline \multirow[t]{2}{*}{ E्व Amps } & $2012-03-26,12: 40$ & Ea Amps & 2 & $3-26,12: 40$ \\
\hline & \multirow[t]{2}{*}{$0.0 \mathrm{~Hz}$} & & \multicolumn{2}{|c|}{$0.0 \mathrm{~Hz}$} \\
\hline & & $\mathrm{A} a \mathrm{c}$ & A avg & A pk \\
\hline 1.43 & A rms & $\mathrm{OL}$ & 1.44 & 1.53 \\
\hline \multirow[b]{2}{*}{1.43} & \multirow[t]{2}{*}{ A dc } & $\mathrm{A} / \mathrm{Hz}$ & $\%$ RPL & CF \\
\hline & & OL & 0.01 & 1.08 \\
\hline
\end{tabular}

Parameters of Output Current of IBC using Single Phase Clamp on Power Quality Analyzer E्व Amps 2012-03-26, 12:42 可 Amps $2012-03-26,12: 42$

\begin{tabular}{|l|l|}
\hline 0.42 & A rms \\
\cline { 1 - 1 } 0.42 & A dc \\
\hline
\end{tabular}

\begin{tabular}{|c|c|c|}
\hline \multicolumn{1}{c}{ A ac } & A avg & A pk \\
\hline OL & $\mathbf{0 . 4 3}$ & $\mathbf{0 . 5 2}$ \\
\hline A/Hz & \%RPL & CF \\
\hline OL & $\mathbf{0 . 0 1}$ & $\mathbf{0 . 1 2}$ \\
\hline
\end{tabular}

Figure 18. Parameters of input and output currents of directly coupled IBC

phase, clamp-on power quality analyzer. The power quality analyzer also gave a measure of the ripple percentage in both the current and voltage on both the input and output sides.

Figure 19 shows the voltage and current waveforms observed using the power quality analyzer at both the input and output sides of the directly coupled IBC. As per the simulation results for an input of $15.24 \mathrm{~V}$ and current of $1.75 \mathrm{~A}$, the output of the IBC was $48.3 \mathrm{~V}$ and $0.48 \mathrm{~A}$. The ripple percentage was $0.008 \%$ for input current, $0.012 \%$ for output voltage, and $0.008 \%$ for output current. As per the hardware results for an input of $15.08 \mathrm{~V}$ and current of $1.43 \mathrm{~A}$, the output of the IBC was $46.94 \mathrm{~V}$ and $0.42 \mathrm{~A}$. The ripple percentage was $0.01 \%$ for input current, $0.02 \%$ for output voltage, and $0.01 \%$ for output current. Hence, the simulation and hardware results were verified.

\section{Conclusions}

In this paper, a comparative analysis of the performance of conventional boost converters and different 
Input Voltage and Input Current

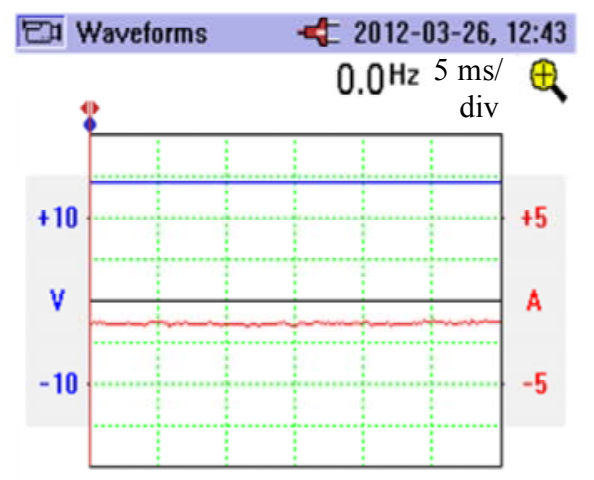

Output Voltage and Output Current

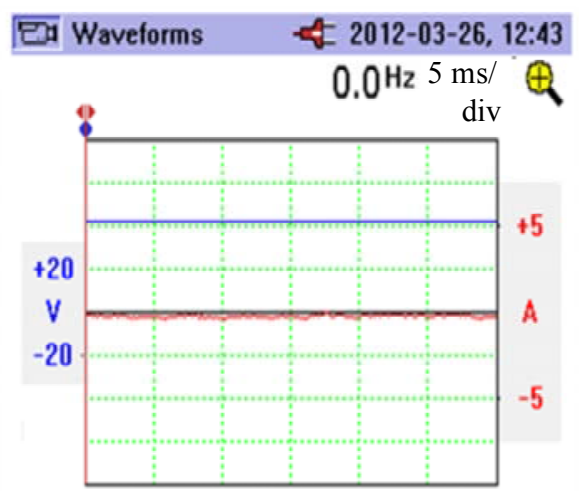

Figure 19. Voltage and current waveforms measured at both input and output sides of the directly coupled IBC

types of IBC interfaced with the SPV panel has been carried out. The parameter chosen for the analysis was the percentage ripple in the input and output currents, and output voltage. From the simulation results, it was found that IBC with directly coupled inductors reduced the ripple to a greater extent as compared to that of the other boost converter topologies. Hence, the value of the filter capacitor used was reduced. The IBC with directly coupled inductors was implemented in hardware, and the simulation results were verified with results obtained through physical experimentation.

\section{Acknowledgment}

The authors wish to thank the management of SSN College of Engineering, in Chennai, India, for providing all the facilities to carry out this work.

\section{References}

Braga HAC, Barbi I (1999), A 3-kW unity-power-factor rectifier based on a two-cell boost converter using a new parallel connection technique. IEEE Transactions on Power Electronics 14:209-217.

Duffie JA, Beckman WA (2006), Solar Engineering of Thermal Processes. Hoboken, John Wiley Sons, $3^{\text {rd }}$ edition.

Gow A, Manning CD (1996), Development of a model for photovoltaic arrays suitable for use in simulation studies of solar energy conversion systems. Power Electronics and Variable Speed Drives, Conference Publication 429:69-74.

Ho CNM, Breuninger H, Pettersson S, Escobar G, Serpa L, Coccia A (2011), A practical implementation of an interleaved boost converter using $\mathrm{SiC}$ diodes for PV applications. $8^{\text {th }}$ International Conference on Power Electronics-ECCE Asia 372-379.
Hussein KH, Muta L, Hoshino T, Osakada M (1995), Maximum photovoltaic power tracking: An algorithm for rapidly changing atmospheric conditions. Proc. IEE Proc.-Generation, Transmiss. Distrib. 142:59-64.

Ibrahim S, Saban O (2010), Multifunctional interleaved boost converter for PV systems. IEEE International

Symposium on Industrial Electronics (ISIE), 951-956.

Lee P, Lee Y, Cheng DKW, Liu X (2000), Steady-state analysis of an interleaved boost converter with coupled inductors. IEEE Trans. on Industrial Electronics 47:787-795.

Phani KKS, Veerachary M (2006), PV power tracking through utility connected single-stage inverter. Power Electronics, Drives and Energy Systems, PEDES '06. International Conference 1-6.

Rashid MH (2001), Power Electronics Handbook, 1st edition. From http://rapidlibrary.com/e/electronics+handbook+pdf/. Accessed Nov 2012.

Salas V, Olias E, Barrado A, Lazaro A (2006), Review of the maximum power point tracking algorithms for stand-alone photovoltaic systems. Solar Energy Materials and Solar Cells 90:1555-1578.

Shin HB, Park JG, Chung SK, Lee HW, Lipo TA (2005), Generalized steady-state analysis of multiphase interleaved boost converter with coupled inductors. Proc. IEE Electronics Power Application 152:584-594.

Thounthong P, Sethaku P, Rael S, Davat B (2008), Design and implementation of 2-phase interleaved boost converter for fuel cell power source. Proc. International Conference on Power Electronics, Machines, and Drives, PEMD 91-95.

Tseng SY, Shiang JZ, Chang HH, Jwo WS, Hsieh CT (2007), A novel turn-on/off snubber for interleaved boost converter. IEEE 38th Annual Power Electronics Specialists Conference (PESC '07) 2718-2724. 
Veerachary M, Senjyu T, Uezato K (2001), Small-signal analysis of interleaved dual boost converter. International Journal of Circuit Theory and Applications 29:575-589.

Veerachary M, Senjyu T, Uezato K (2003), Neural network based maximum power point tracking of coupled inductor interleaved boost converter supplied PV system using fuzzy controller. IEEE Transactions on Industrial Electronics 50:749758.

Villalva MG, Gazoli JR, Filho ER (2009), Comprehensive approach to modeling and simula- tion of photovoltaic arrays. IEEE Transactions on Power Electronics 24:1198-1208.

Walker G (2001), Evaluating MPPT converter topologies using a MATLAB PV model. Journal of Electronics of England and Australia 21:45-55.

Wang CY (2009), Investigation on Interleaved Boost Converters and Applications. Dissertation submitted o the Faculty of the Virginia Polytechnic Institute and State University in partial fulfillment of the requirements for the degree of Doctor of Philosophy. 